
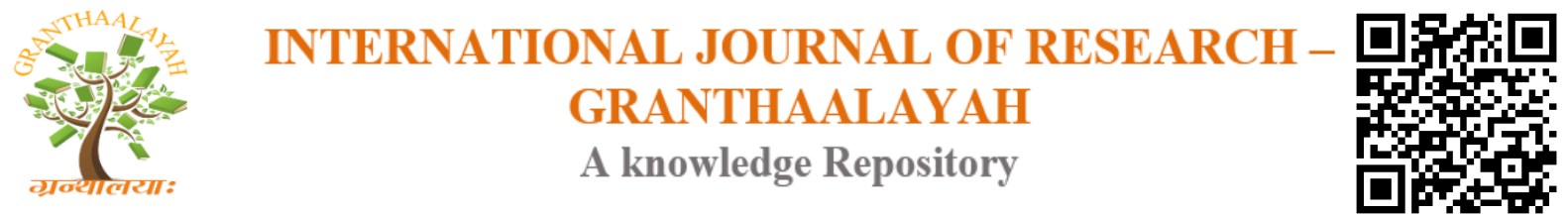

Science

\title{
CORRELATIONS AMONG GRAIN YIELD, YIELD AND WEED ATTRIBUTES OF MAIZE (ZEA MAYS L.) AS INFLUENCED BY WEED CONTROL METHOD AND POULTRY MANURE RATE IN KANO STATE NIGERIA
}

\author{
M. S. Garko ${ }^{* 1}$, K. D. Dawaki ${ }^{2}$, M. A. Yawale ${ }^{3}$, I. B. Mohammed ${ }^{4}$, A. Y. Yaroson ${ }^{5}$ \\ ${ }^{1,2,3}$ Department of Crop Science Faculty of Agriculture, Kano University of Science and \\ Technology, Wudil, Nigeria \\ ${ }^{4}$ Department of Agronomy, Faculty of Agriculture, Bayero University Kano Nigeria \\ ${ }^{5}$ Department of Crop Production Federal Collage of Forestry Jos Plateau State, Nigeria
}

\begin{abstract}
Field trials were conducted during the rainy season of 2017 at Teaching and Research Farm of Bayero University and Kano State Livestock development Centre Dangora. To determine the magnitude and nature of the association between growth characters and grain yield of maize, as well as the percentage contribution of each of this independent variable on the dependent variable (yield).The trails consist of six weed control methods, three levels of poultry manure and three varieties of maize. The experiment was laid out in a split-split plot design with variety allocated to the main plot, poultry manure to the sub-plot while weed control method to the sub-sub plot, and was replicated three times. Grain yield correlated positively and significantly with growth and yield characters evaluated while weed dry weight and weed index were highly negatively correlated. The direct and indirect contributions results indicate that plant height had the highest direct contribution at BUK and Dangora in 2016 and Doka 2017 while plant dry matter accumulation had the highest direct contribution at Dangora in 2017. Cob diameter had the least direct effect in the study; the highest indirect effect was from cob diameter through plant height. The percentage individual contribution to grain yield showed that plant height made the highest contribution at BUK and Dangora in 2016, while cob diameter at both locations and plant dry matter at Dangora resulted in the least contribution. The combined contribution of dry matter and 100 -seed weight was the highest positive contribution at BUK and that of plant height via 100seed weight all in 2016 while cob length via 100 -seed weight made the least negative contribution at BUK.
\end{abstract}

Keywords: Correlation; Path Analysis; Quantitative Component; Maize.

Cite This Article: M. S. Garko, K. D. Dawaki, M. A. Yawale, I. B. Mohammed, and A. Y. Yaroson. (2020). "CORRELATIONS AMONG GRAIN YIELD, YIELD AND WEED ATTRIBUTES OF MAIZE (ZEA MAYS L.) AS INFLUENCED BY WEED CONTROL METHOD AND POULTRY MANURE RATE IN KANO STATE NIGERIA.” International 
Journal of Research - $\quad$ Granthaalayah, 8(4), 275-284. https://doi.org/10.29121/granthaalayah.v8.i4.2020.15.

\section{Introduction}

Maize (Zea mays L.) is cultivated in rainy and dry seasons for grain as well as for fodder production in developing countries. Therefore, the demand for maize is increasing due to increase in population and growing poultry and livestock industries. Being short duration crop, the farmers prefer to grow maize for getting higher income. The crop is regarded as the most important cereal crop in Sub-Saharan Africa (IITA, 2013). It ranks third among cereal crops produced in Nigeria after sorghum and millet (FAO, 2012). Production of meat, eggs and dairy products (like milk and yoghurt) would be difficult without maize as it is highly desirable because of it is high energy and feed value of the kernel, leaf and stem, it is also used for the production of bio-fuels in the developed countries and also for the manufacture of pharmaceuticals and industrial products such as starch, ethanol and plastic, and as a base for antibiotic production across the globe (Tesfay et al., 2014). Due to its expanded uses and high production potential, in agro industries, it is recognized as a leading commercial crop of great agronomic value in the economies of many countries including Nigeria (Rasheed et al., 2003).

Weed infestation, imbalanced fertilizers, use of local or inappropriate varieties or not suitable for the location planted and several other factors severely affect the maize production (Chikoye $e t$ al., 2009; IITA, (2013) and Khan et al., 2013). Yield losses estimates due to weed infestation vary considerably worldwide depending on the weed species, intensity of weed population and competitive ability of the crop, and duration of weed infestation (Mahadi et al., 2012). Weeds not controlled within two to six weeks after maize emergence can cause grain losses between 35 and $70 \%$ Chikoye et al. (2009).

Maize is an exhaustive crop and thus uses the nutrients at all the stages of its growth and development. Among the essential nutrients required are nitrogen $(\mathrm{N})$ which plays a vital role in overall production of the crop (Santos et al., 2015) as it is linked with dark green coloration of the vegetative parts, and leaf production that significantly increase dry matter production (Rashidi et al., 2015). Phosphorus (P) is considered to be the second most important nutrient, as it influences the growth and yield related traits of plants as responsible for the improvement of seed vigor (Seyyedi et al., 2015). Adeboye et al. (2011) reported low organic matter content low cations exchange capacity and low inherent fertility as the characteristic features of Nigerian soils. He further identified nitrogen and phosphorus as the most limiting nutrients in the soil of savanna regions. There is a problem of poor and inappropriate crop residue management practices where farmers harvest all part of the crop or burn it without leaving the residues for incorporation in to the soil so as to improve the fertility of the soil. Such also helps to increase the soil degradation, poor holding capacity and many other problems that led to the decrease in maize yield in Kano Sudan Savanna.

Yield depends upon the interplay number of interrelated attributes. These include mainly plant genetic makeup, environmental factors, Agronomic and other management factors. Genetic differences exist among different crops types and even within different crop varieties. The estimate of genetic parameters serves as a useful tool for its improvement. However, the results pointed out 
that, traits of agronomical importance can be correlated to each other at different magnitude in order to assess their contributions to the yield of the crop. In a related development Adekoya et al., 2014 pointed out that the suitable knowledge of the associations between yield and its related characters could appreciably enhance the efficiency of the crop improvement through the utilization of the appropriate selection indices. It is very important for a researcher to know the extent of the relationship between yield and other plant attributes which will serve as a basic tool for selecting best crop types.

Path coefficient analysis is a standardized partial regression coefficient that allows partitioning of correlation coefficient into direct and indirect effects of various traits towards dependent variable, and also helps in assessing the cause effect relationship as well as effective selection. Path analysis plays an important role in determining the degree of relationship between yield and its components Nemati et al., (2009). However, Mohammad et al. (2003) determined the interrelationship between grain yield and its components from eighteen maize lines/ hybrids, using genotypic correlation and path coefficient analysis. Grain yield was positively and significantly associated with plant and ear height, ear diameter, number of grains per ears, number of grains per row and 1000-grain weight.

This study was conducted to determine the magnitude and nature of the association between growth characters and grain yield of maize, as well as the percentage contribution of each of this independent variable on the dependent variable (yield).

\section{Materials and Methods}

\subsection{Experimental Sites}

Field experiments was conducted during the rainy seasons of 2016 and 2017 at the Teaching and Research Farm of Faculty of Agriculture, Bayero University Kano Nigeria (Lat $11^{\circ} 58^{\prime}$ N, and long $8^{\circ} 26^{\prime}$ E and $475 \mathrm{~m}$ above sea level) and Livestock Development Centre, Dangora, Kiru Local Government Area Kano State Nigeria (lat $11^{\circ} 30^{\prime} \mathrm{N}$, and long $7^{\circ} 82^{\prime} \mathrm{E}$ and 670m above sea level) for 2016 season while that of BUK location.

\subsection{Treatments and Experimental Design}

The experiment consist of factorial combinations of six weed control method using two preemergence and two post-emergence herbicides (S-Metolachlor $290 \mathrm{~g} / \mathrm{L}+$ Atrazine $370 \mathrm{~g} / \mathrm{l}$ at $2.0 \mathrm{~kg}$ a.i. $\mathrm{ha}^{-1}$ followed by Nicosulfuron at $100 \mathrm{~g}$ a.i.ha ${ }^{-1}$, S-Metolachlor $290 \mathrm{~g} / \mathrm{l}+$ Atrazine $370 \mathrm{~g} / \mathrm{l}$ at $2.0 \mathrm{~kg}$ a.i. ha ${ }^{-1}$ followed by Bentazone $480 \mathrm{~g} / \mathrm{l}$ at $2.5 \mathrm{~kg}$ a.i. $\mathrm{ha}^{-1}$, Metolachlor $375 \mathrm{~g} / \mathrm{L}+$ Terbuthylazine $125 \mathrm{~g} / \mathrm{L}+$ Mesotrione $37.5 \mathrm{~g} / \mathrm{l}$ at $2.5 \mathrm{~kg}$ a.i ha ${ }^{-1}$ followed by Nicosulfuron at $100 \mathrm{~g}$ a.i. ha ${ }^{-1}$, Metolachlor $375 \mathrm{~g} / \mathrm{l}+$ Terbuthylazine $125 \mathrm{~g} / \mathrm{l}+$ Mesotrione $37.5 \mathrm{~g} / \mathrm{l}$ at $2.5 \mathrm{~kg}$ a.i ha ${ }^{-1}$ followed by Bentazone $480 \mathrm{~g} / \mathrm{l}$ at $2.5 \mathrm{~kg}$ a.i. ha ${ }^{-1}$, Two hoe weeded at 3 and 6 WAS and Weedy check) with three levels of poultry manure $\left(0,4\right.$, and $\left.8 \mathrm{tha}^{-1}\right)$ and NPK fertilizer at the rate of $120 \mathrm{~kg} \mathrm{~N}, 60 \mathrm{~kg} \mathrm{P}$ and $60 \mathrm{~kg} \mathrm{~K} \mathrm{ha}^{-1}$ and three maize varieties (SAMMAZ 15, SAMMAZ 21 and SAMMAZ 35). Poultry manure was applied 2 WAS before sowing while pre-emergence herbicide was applied a day after sowing and post-emergence herbicide was applied at $6 \mathrm{WAS}$. The treatments were laid out in a split-split plot design with variety allocated to the main plot, poultry manure to the sub-plot while weed control method to the sub-sub plot, and was replicated three times. 


\subsection{Cultural Practice}

The field was harrowed and made in to ridges of $0.75 \mathrm{~m}$; plots were laid out with three (3) replications and an ally of $1 \mathrm{~m}$ between plots and $1.5 \mathrm{~m}$ between replications. The gross and net plot consists of six (6) ridges of $0.75 \mathrm{~m}$ of $3 \mathrm{~m}$ long $\left(13.5 \mathrm{~m}^{2}\right)$. The two (2) inner ridges were used as net plots $\left(4.5 \mathrm{~m}^{2}\right)$. The poultry manure was applied manually by opening the top of the ridges and apply at about $15 \mathrm{~cm}$ depth and covered manually using hoe. Two seeds were planted at a spacing of $0.75 \mathrm{~m}$ by $0.25 \mathrm{~m}$ and later thinned to one plant per stand. Herbicides were applied as per treatments using knapsack sprayer fitted with the green deflector nozzles, set at a pressure of $2.1 \mathrm{Kg} \mathrm{cm}^{2}$ that gave a spray of $250 \mathrm{l}^{-1}$.

The plot received $60 \mathrm{~kg} \mathrm{ha}^{-1} \mathrm{~N}, \mathrm{P}_{2} \mathrm{O}_{5}$ and $\mathrm{K}_{2} \mathrm{O}$ fertilizer inform of NPK (15:15:15) at 2 WAS, then addition of $60 \mathrm{~kg} \mathrm{~N} \mathrm{ha}^{-1}$ was done inform of urea at $5 \mathrm{WAS}$. Harvesting was done by removing the cobs after they mature, ears from the net plots were removed and de-husked manually and the cobs were sun dried and later thrashed and winnowed to obtain clean grains.

\subsection{Observations and Data Collection}

Data was collected accumulation on, plant height, leaf area index, chlorophyll content, crop injury scores dry matter, at 10 WAS. Weed dry weight, weed index, weed control efficiency crop resistance index were collected from a $0.25 \mathrm{~m}^{2}$ quadrant at $10 \mathrm{WAS}$, cob length, cob girth 100kernel weight and grain yield at harvest.

\subsection{Statistical Analysis}

The mean data collected were subjected to simple correlation analysis as described by Little \& Hill (1978). The direct and indirect effects on and individual and combined (two factors) contributions of yield components to seed yield were determined using path analysis as described by Dewey \& $\mathrm{Lu}$ (1959).

\section{Results and Discussions}

In the combined (2016 and 2017) results, there was positive and highly significant correlation between grain yield and plant height, leaf area index, chlorophyll content, dry matter accumulation, crop resistance index, weed control efficiency at $12 \mathrm{WAS}$ and also with cob length, cob diameter and 100-grain weight at harvest across both locations. However, crop injury, weed dry weight and weed index were highly negative correlated with grain yield across both locations and seasons. The strongest relationship between a growth parameter and seed yield in the combined data was that recorded between plant height and grain yield $\left(r=0.742^{* *}\right)$ at BUK and $\left(r=0.857^{* *}\right)$ at Dangora, while is the strongest growth relationship obtained in this study. The results revealed an inter-dependency between growth and yield characters as important yield determinants characters to be use for yield improvements in maize. This finding is similar to that of Kumar and Kumar (2000) and Bello, et al. (2010), they all stressed out that plant height, higher number of grains per rows, ear weight, ear length and number of grains per ear could be selected for yield improvement. Significant positive correlation was observed among the two important yield components viz. cob 
length with number of kernel per row. These results are in harmony with that of Nataraj et al. (2014).

Weed dry weight and weed index was significantly highly negative correlated to grain yield indicating serious reduction in grain yield The results are in consonance to that of Daniya et al. (2013) who reported significantly negatively correlations between weed characteristics to the final seed yield in sesame production. At BUK, The combined data indicate that, the direct contribution of the growth and yield components to seed yield measured were positive (Table 2), except that of cob length (-0.0925) which has a negative contribution. Plant height (0.4086) made the greatest contribution to grain yield and was closely followed by 100 -seed weight $(0.3971)$. While the weakest direct effect was from cob diameter (0.1580). At Dangora, the combined data indicate that, the direct contribution of the growth and yield components to seed yield measured were all positive (Table 2). Plant height (0.6742) made the greatest contribution to grain yield and was closely followed by Total dry matter production by the plant (2.5500). While the weakest direct effect was from cob diameter (0.0002). This probably meant that maize grain yield was dependent on plant height, 100-seed weight and dry matter accumulation.

Plant height made the highest percent contribution to seed yield (16.70 and 45.46\%) at BUK and Dangora in the combined (2016 and 2017) years (Figure I and II). This was followed by 100 -seed weight (15.77 and 5.23\%) at BUK and Dangora and Total dry matter per plant (2.59\%) at BUK and cob length (3.14\%) at Dangora. The greatest and positive combined contribution of $9.14 \%$ was made by plant height via 100-grain weight at BUK and 8.09 at Dangora, followed by total dry matter via 100 -grain weight $(3.60 \%)$ for BUK and $(4.23 \%)$ through plant height via cob length for Dangora. The individual or combined percent contribution of two parameters to maize grain yield showed that plant height, 100-seed weight, and plant height via 100-grain weight made the highest contribution to grain yield. This probably could be attributed to the fact that the Taller plants produced was capture and translocated more assimilate to the developing heavier seeds which in turn resulted in higher grain yield and further demonstrated that, direct selection for these traits will improve grain yield $\left(\mathrm{t} \mathrm{ha}^{-1}\right)$ in maize.

The results were supported by earlier findings of Adu et al., (2016) for the number of ears harvested and Sesay, et al., (2017) for field weight (kg). Adekoya et al., 2014 pointed out that the suitable knowledge of the associations between yield and its related characters could appreciably enhance the efficiency of the crop improvement through the utilization of the appropriate selection indices like plant and ear height, ear diameter, number of grains per ear, number of grains per row and 1000-grain weight. The residual effects permit precise explanation about the pattern of interaction of other possible components of yield. The residual effect recorded was 43.19 for BUK and 31.73 for Dangora; it indicates the studied characters contribute 56.81 and $68.27 \%$ of variations in yield of maize across the two locations. 
Table 1: Simple Correlation Coefficient between Grain Yield and Growth, Weeds and Yield Parameters of Maize as Influenced by Varieties,

\begin{tabular}{|c|c|c|c|c|c|c|c|c|c|c|c|c|c|}
\hline GYL & 1 & 2 & 3 & 4 & 5 & 6 & 7 & 8 & 9 & 10 & 11 & 12 & $\overline{13}$ \\
\hline 1 & 1.000 & & & & & & & & & & & & \\
\hline 2 & $0.742 * *$ & 1.000 & & & & & & & & & & & \\
\hline 3 & $0.598 * *$ & $0.566 * *$ & 1.000 & & & & & & & & & & \\
\hline 4 & $-0.461 * *$ & $-0.423 * *$ & $-0.390 * *$ & 1.000 & & & & & & & & & \\
\hline 5 & $-0.730 * *$ & $0.641 * *$ & $0.435 * *$ & $-0.356 * *$ & 1.000 & & & & & & & & \\
\hline 6 & $0.603 * *$ & $0.518 * *$ & $0.413 * *$ & $-0.554 * *$ & $0.600 * *$ & 1.000 & & & & & & & \\
\hline 7 & $-0.460 * *$ & $-0.520 * *$ & $-0.571 * *$ & $0.606^{* *}$ & $-0.373 * *$ & $-0.529 * *$ & 1.000 & & & & & & \\
\hline 8 & $0.299 * *$ & $-0.443 * *$ & $-0.458 * *$ & $-0.458 * *$ & $-0.368 * *$ & $-0.366 * *$ & $0.447 * *$ & 1.000 & & & & & \\
\hline 9 & $0.245^{*}$ & $0.299 * *$ & $0.396 * *$ & $-0.446 * *$ & $0.286^{* *}$ & $0.347 * *$ & $-0.630 * *$ & $-0.468 * *$ & 1.000 & & & & \\
\hline 10 & $0.267 *$ & $0.255^{*}$ & $0.364 * *$ & $-0.397 * *$ & $0.284 * *$ & $0.447 * *$ & $-0.507 * *$ & $-0.246 * *$ & $0.477 * *$ & 1.000 & & & \\
\hline 11 & $0.503 * *$ & $0.431 * *$ & $0.510^{* *}$ & $-0.581 * *$ & $0.417 * *$ & $0.497 * *$ & $-0.611 * *$ & $-0.443 * *$ & $0.457 * *$ & $0.427 * *$ & 1.000 & & \\
\hline 12 & $0.524 * *$ & $0.407 * *$ & $0.495 * *$ & $-0.540 * *$ & $0.415 * *$ & $0.525 * *$ & $-0.556 * *$ & $-0.421 * *$ & $0.418 * *$ & $0.423 * *$ & $0.811 * *$ & 1.000 & \\
\hline 13 & $0.732 * *$ & $0.563 * *$ & $0.536^{* *}$ & $-0.466 * *$ & $0.540 * *$ & $0.487 * *$ & $-0.442 * *$ & $-0.513 * *$ & $0.279 * *$ & $0.191 * *$ & $0.532 * *$ & $0.479 * *$ & 1.000 \\
\hline
\end{tabular}

Table 2: Simple Correlation Matrix between Grain Yield per hectare and Growth and Yield Components of Maize as Influenced by Varieties,

Poultry Manure and Weed Control Method at Dangora 2016 and 2017 Combined.

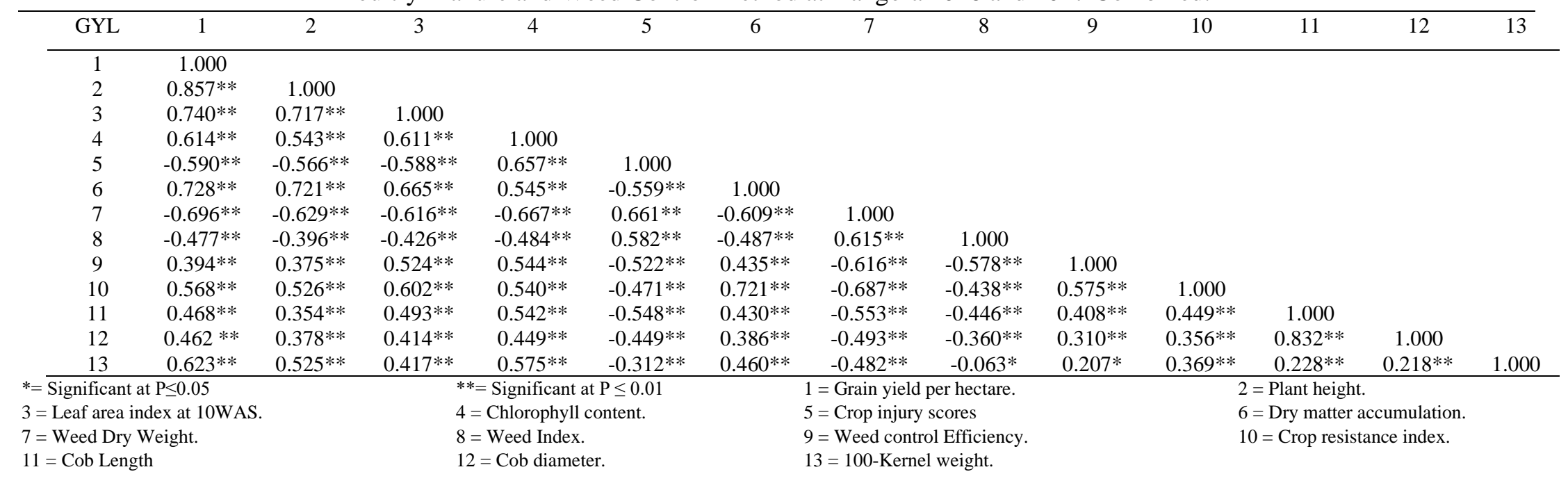


Table 3: The Direct and Indirect Contribution of Some Growth and Yield Characters to Grain yield (t ha $^{-1}$ ) of Maize at 12WAS at BUK, and Dangora 2016 and 2017, Raining season Combined.

\begin{tabular}{lcccccc}
\hline & $\begin{array}{c}\text { Plant } \\
\text { Height }\end{array}$ & $\begin{array}{c}\text { Total Dry } \\
\text { Matter }\end{array}$ & Cob Length & $\begin{array}{c}\text { Cob } \\
\text { diameter }\end{array}$ & $\begin{array}{c}\text { 100-Seed } \\
\text { Weight }\end{array}$ & TOTAL \\
\cline { 1 - 3 } Plant Height & $\mathbf{0 . 4 0 8 6}$ & 0.0834 & -0.0399 & 0.0643 & 0.2236 & 0.742 \\
Total Dry Matter & 0.2117 & $\mathbf{0 . 1 6 0 9}$ & -0.0460 & 0.0830 & 0.1934 & 0.603 \\
Cob Length & 0.1761 & 0.0800 & $\mathbf{- 0 . 0 9 2 5}$ & 0.1284 & 0.2113 & 0.503 \\
Cob diameter & 0.1663 & 0.0845 & -0.0750 & $\mathbf{0 . 1 5 8 0}$ & 0.1902 & 0.524 \\
100-grain Weight & 0.2301 & 0.0784 & -0.0492 & 0.0757 & $\mathbf{0 . 3 9 7 1}$ & 0.732 \\
Plant Height & $\mathbf{0 . 6 7 4 2}$ & 1.8400 & 0.0627 & 5.9300 & 0.1200 & 0.857 \\
Total Dry Matter & 0.4861 & $\mathbf{2 . 5 5 0 0}$ & 0.0762 & 0.0606 & 0.1052 & 0.728 \\
Cob Length & 0.2387 & 1.1000 & $\mathbf{0 . 1 7 7 1}$ & 0.0001 & 0.0521 & 0.468 \\
Cob diameter & 0.2549 & 0.0099 & 0.1473 & $\mathbf{0 . 0 0 0 2}$ & 0.0499 & 0.462 \\
100-grain Weight & 0.3540 & 1.1700 & 0.0404 & 3.4200 & $\mathbf{0 . 2 2 8 6}$ & 0.623 \\
\hline
\end{tabular}

Bold $=$ Direct effect

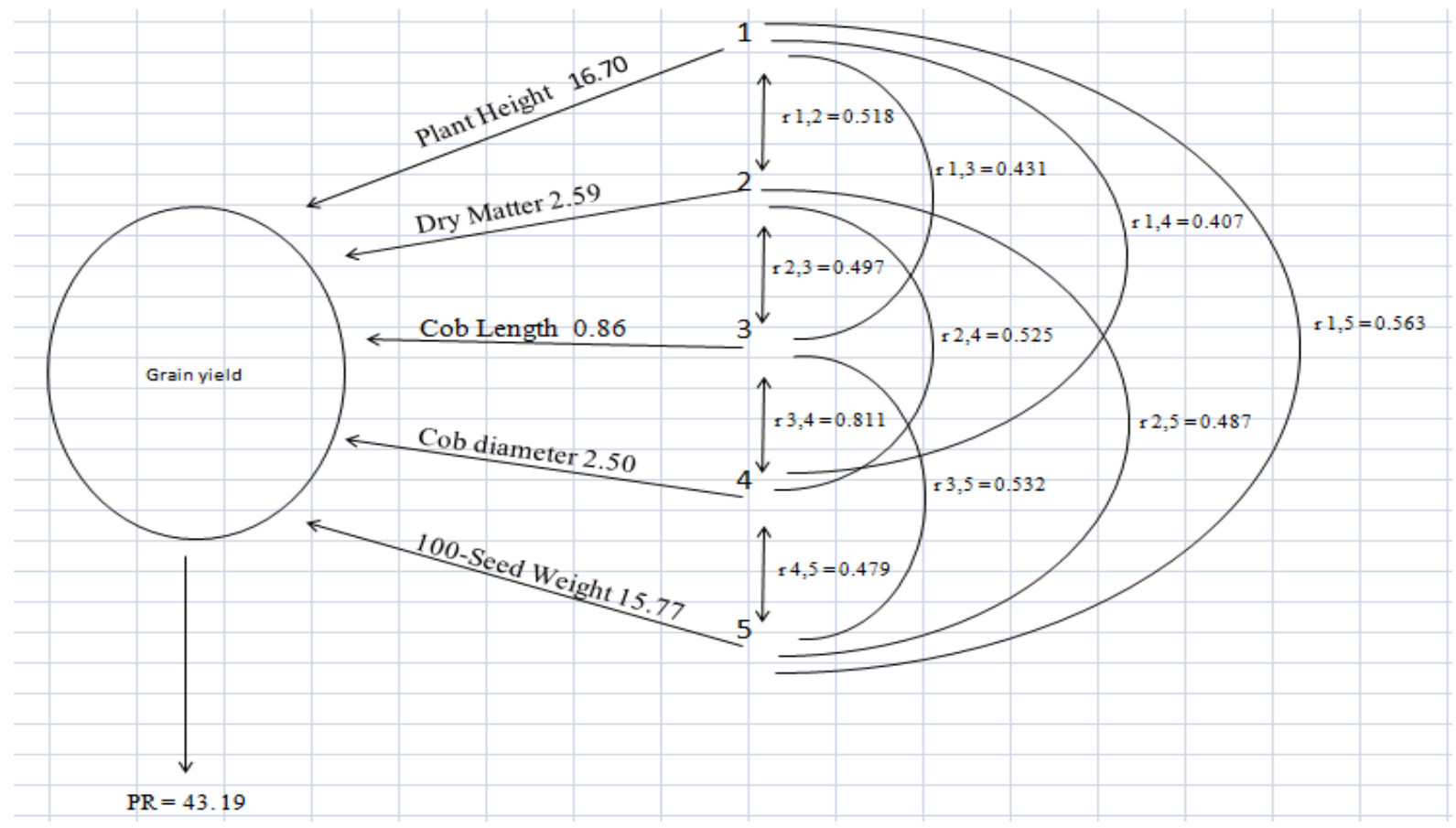

Figure 1: Path Diagram Indication the contribution and Correlation of some character to Grain Yield of Maize as Influenced by Weed Control, Poultry Manure and varietal Differences in Combined at BUK 2016 and 2017 Rainy Seasons. 


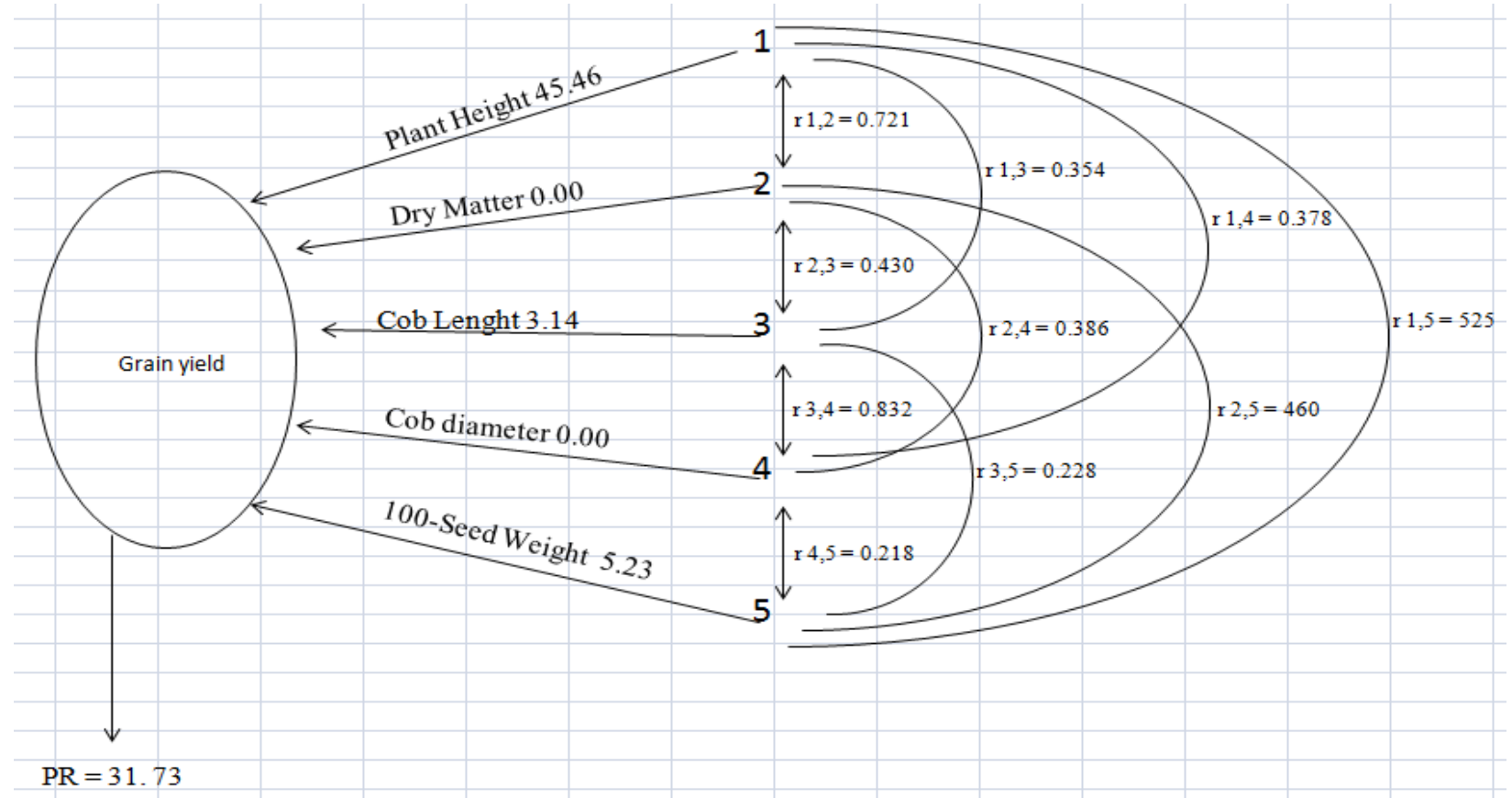

Figure 2: Path Diagram Indication the contribution and Correlation of some character to Grain Yield of Maize as Influenced by Weed Control, Poultry Manure and varietal Differences in Combined at Dangora 2016 and 2017 Rainy Seasons.

\section{Conclusions and Recommendations}

Based on the results obtained from this study, it can be concluded that all the growth and yield characters measured contributed positively and significantly to grain yield, but negatively with weed density and weed dry weights, The highest direct effect to grain yield was by plant height and 100-seeds weight than any growth and yield attributes. The greatest direct effect and individual factor contribution were by plant height and 100-seeds weight. The highest indirect effect was by plant height through 1000 - seed weight; while the highest combined contribution was by plant height via 100-seeds weight. The overall result suggests that due consideration be given to these traits for improving the grain yield of maize.

\section{Acknowledgements}

We thank Centre for dry land Agriculture Bayero University Kano. We also thank the management of Agronomy Department, Bayero University Kano Nigeria; for providing technical support throughout the duration of this study.

\section{References}

[1] Adeboye, M. K. A., Bala, A., Osunde, A. O., Uzoma, A. O., Odofin, A. J. and Lawal, B. A. (2011). Assessment of Soil Quality Using Soil Organic Carbon and Total Nitrogen and Microbial Properties in Tropical Agro-ecosystems. Agricultural Sciences, 2: pp 34-40.

[2] Adekoya, M. A., Ariyo, O. J., Kehinde, O. B. and Adegbite, A. E. (2014), Correlation and path analyses of seed yield in okra (Abelmoschus esculentus (L.) Moench) grown under different cropping seasons. Pertan. Journal Tropical Agricultural Science 37(1), 39-49. 
[3] Adu G. B., Akromah R., Abdulai M. S., Obeng-Antwi, K., Alidu H. and Tengan K. M. L., (2016). Trait association for improved grain yield of extra-early maturing maize hybrids evaluated in the forest and transitional zones of Ghana. Australian Journal of Crop Science.;10 (8):1127-1135.

[4] Bello, O. B., Abdulmaliq, S. Y., Afolabi, M. S., and Ige, S. A. (2010). Correlation and Path Coefficient Analysis of Yield and Agronomic Characters Among Open Pollinated Maize (Zea mays L.) Varieties and their F1Hybrids in a Diallel Cross. African Journal of Biotechnology Vol. 9 (18), pp. 2633-2639.

[5] Chikoye, D., Lum, A. F., Ekeleme, F. and Udensi, U. E. (2009). Weed control in Maize in Nigeria International Journal of Pest Management, Volume 55.

[6] Daniya E., S.A. Dadari, W. B. Ndahi, N. C. Kuchinda, and B. A. Babaji (1023) Correlation and Path Analysis between Seed Yield and some Weed and Quantitative Components in Two Sesame (Sesamum indicum L.) Varieties as influenced by Seed Rate and Nitrogen Fertilizer. Journal of Biology, Agriculture and Healthcare Vol.3, No.15, Pp 12 -16.

[7] Dewey D. R, Lu K. H., (1959). A correlation and path-coefficient analysis of components of crested wheatgrass seed production. Agronomy Journal Vol.51: pp515 - 518.

[8] FAO, Food and Agriculture Organization of the United Nations, (2012). Production Year Book. Food and Agriculture Organization of the United Nations, Rome, Italy.

[9] IITA, International Institute of Tropical Agriculture (2013). Crop [Internet]. Nigeria: International Institute of Tropical Agriculture [Cited 2013 Jan 13]. Available from http://www.iita.org.

[10] Khan, M. A., Marwat, K. B., Khan, N. and Khan, I. A. (2003). Efficacy of Different Herbicides on the Yield and Yield Components of Maize. Asian Journal of Plant Science 2: pp 300-304.

[11] Kumar M. V. N, Kumar S. S., (2000). Studies on character association and path coefficients for grain yield and oil content in maize (Zea mays L.). Ann. Agric. Res. 21:73-8.

[12] Little, and Hills (1978). Agricultural Experimentation: Design and Analysis. John Wiley and Sons, Inc. New York 150.

[13] Mahadi, M. A., Dadari, S. A., Tanimu, B., Kuchinda, N. C., Sharifai, A. I. and Bature, M. S. (2012). Effects of Weed Control and Cow Dung Manure on Growth Indices of Quality Protein Maize. Bayero Journal of Pure and Applied Sciences, 5(2):148 - 155.

[14] Muhammad B. A., Muhammad R., Muhammad S.T., Amer H., Tariq M. and Muhammad S.A. (2003). Character association and path coefficient analysis of grain yield and yield Components in maize. Pakistan Journal of Biological Science Vol. 6 (2); pp 136-138.

[15] Nataraj, V., J. P. Shahi and V. Agarwal. 2014. Correlation and path analysis in certain inbred genotypes of maize (Zea Mays L.) at Varanasi. International Journal of Innovative Research and Development Vol. 3 (1): pp14-17.

[16] Nemati A., Sedghi M., Sharifi R. S. and Seiedi M. N., (2009). Investigation of correlation between traits and path analysis of corn (Zea mays L.) grain yield at the climate of Ardabil region (Northwest Iran). Not. Bot. Hort. Agrobot. Cluj 37(1): pp 194-198.

[17] Rasheed, M., Hussaini, A. and Mahmood, T. (2003). Growth Analysis of Hybrid Maize as Influenced by Planting Techniques and Nutrient Management. International Journal of Agriculture and Biology, 5(2): $169-171$.

[18] Rashidi, S., A. Ebadi, G. Parmoon, S. Jahanbakhsh and Z. Haghighat. (2015). Effect of nitrogen source on bean growth under water deficit conditions. The Philipp. Agric. Sci., 98(3): 279-285.

[19] Santos, G. A., G. H. Korndorfer and H. S. Pereira. (2015). Methods of adding micronutrients to a NPK formulation and maize development. Journal of Plant Nutrition DOI: 10.1080/01904167.2015.1087569.

[20] Sesay S., Ojo D. K, Ariyo O. J, Meseka S., Fayeun L. S., Omikunle A. O. and Oyetunde A. O. (2017) Correlation and path coefficient analysis of top-cross and three-way cross hybrid maize populations. African Journal of Agricultural Research.;12(10):780-789.

[21] Seyyedi, S. M., M. K. Hosseini, P. R. Moghaddam and H. Shahandeh. (2015). Effects of phosphorus and seed priming on seed vigor, fatty acids composition and heterotrophic seedling 
[Garko et. al., Vol.8 (Iss.4): April 2020]

ISSN- 2350-0530(O), ISSN- 2394-3629(P)

https://doi.org/10.29121/granthaalayah.v8.i4.2020.15

growth of black seed (Nigella sativa L.) grown in a calcareous soil. Industrial Crops Production, Vol.74: 939-949.

[22] Tesfay, A, Amin, M., and Mulugeta N. (2014) Management of Weeds in Maize (Zea mays L.) through Various Pre and Post Emergency Herbicides. Adv Crop Sci. Tech 2: V151.

* Corresponding author.

E-mail address: sanigarkom@yahoo.com 